\title{
articles COLLABORATIVE LEARNING IN DIGITAL JOURNALISM: Using JCollab for journalists' education
}

Copyright (c) 2014 SBPjor / Associação Brasileira de Pesquisadores em Jornalismo

\author{
KELLYANNE CARVALHO ALVES \\ Universidade Federal da Paraíba \\ GUIDO LEMOS DE SOUZA FILHO \\ Universidade Federal da Paraíba \\ SANDRA MOURA \\ Universidade Federal da Paraíba \\ FERNANDO BRITO \\ Universidade Federal da Paraíba
}

\begin{abstract}
This essay presents the results of the application of JCollab for journalists ' education. JCollab is a system developed for automating the management of the production of television news programs, organizing the interactive process of producing a collaborative news program that involves, in addition to students and teachers, ordinary people. The system was successfully tested with journalism students at the Federal University of Paraíba (Brazil). In evaluations which made use of JCollab, it was noted that this teaching approach facilitated communication between the community of users' members and stimulated teamwork, resulting in a truly collective and collaborative process.
\end{abstract}

Keywords: Collaborative learning. Virtual communities. Audiovisual content and participatory journalism.

\section{COLABORAÇÃO NO JORNALISMO DIGITAL: Uma aplicação da ferramenta JCollab para a formação de jornalistas}

RESUMO - Este artigo apresenta os resultados da aplicação da JCollab, uma ferramenta de criação e gestão de telejornais por comunidades virtuais. A ferramenta foi testada com êxito na formação de jornalistas na Universidade Federal da Paraíba (Brasil). O objetivo do projeto é estruturar o desenvolvimento de um processo interativo de produção telejornalística, que envolve além de alunos e professor, o cidadão comum. Este tipo de aprendizagem facilitou a comunicação entre os membros e estimulou o trabalho em grupo, o que resultou num processo que se realizou de forma efetivamente coletiva e colaborativo.

Palavras chave: Aprendizagem colaborativa. Comunidades virtuais. Conteúdos audiovisuais e jornalismo participativo.

\section{COLABORACIÓN ELECTRÓNICA EN EL PERIODISMO DIGITAL: una aplicación de la herramienta JCollab para la formación de periodistas}

RESUMEN - Este artículo presenta los resultados de la aplicación de JCollab, una herramienta de creación y gestión de telediarios por comunidades virtuales, probada con éxito en la formación de periodistas en la Universidad Federal de Paraíba (Brasil). El objetivo es estructurar el desarrollo de un proceso interactivo de producción de periodismo televisivo colaborativo, en el que participa, además de alumnos y el profesor, al ciudadano de a pie. Este tipo de aprendizaje facilitó la comunicación entre los miembros y el estímulo del trabajo en equipo, lo cual tuvo como resultado un proceso efectivamente colectivo y colaborativo. Palabras clave: Aprendizaje colaborativo. Comunidades Virtuales. Contenidos audiovisuales y periodismo participativo. 


\section{INTRODUCTION}

In current debates on communication and education, there has been a palpable manifestation of analyses on collaborative processes. Technological progress has generated changes in different areas of social life, affecting significantly work design, production and reception systems, as well as the teaching-learning relationship.

In communication, more specifically in journalism, technologies have caused an increase in anonymous protagonists, who appear to have become prominent through the insertion of new digital resources, expanding their participation in journalistic production processes.

Technological progress and the emergence of the Internet have extended openings for ordinary people to produce content. In this digital culture, the terms collaborative, participatory, citizen journalism and open source are used synonymously to define this type of journalism. Some authors make a distinction between these terms, though there is no consensus on such distinctions.

Gillmor (2004, p. 61) notes that the practice of participatory journalism is a result of the audience's need for greater transparency in communication. Bowman and Willis (2003) are among the authors who discuss how the empowered audience is shaping the future of news and information, via so-called participatory journalism, whereby the audience produces news reports and information material, such as photographs, videos, infographics, text, etc. Thus, participants are encouraged to submit their views, comments, criticisms and observations, as well as to propose new approaches and different themes.

In the field of participatory culture, Jenkins discusses the producers and consumers of media as participants - and not as passive spectators - that interact within a complex system of rules, created to be dominated collectively. "No group gets control access and participation" (JENKINS, 2009, p. 52). The author also states that "the public that has gained power with new technologies and is taking up space at the intersection between old and new media, are demanding the right to participate intimately in the culture" (p. 53).

Although Jenkins has focused his study on the entertainment culture - rather than journalism - it can be incorporated into collaborative journalism, whereas technologies reduce production and distribution costs. Moreover, it has allowed citizens to comment, share and appropriate content, and put it into circulation, which is what ordinary people, who want to contribute to the production process of the news, do. 
Authors such as Belochio (2009), Amorim and Finger (2008) and Brambilla (2005) have highlighted confusion regarding the use and definition of the collaborative activities of internet journalism. From one perspective, the collaborative context in Web 2.0 is applied in collaborative projects receiving network definition. Based on Baumgartel's definition, Brunet (2009, p.75) describes "net-work" as artworks developed specially for web. In his view, 'network' is the work in cooperation that emerges through collaboration between people.

In this sense, users can be described as participants, collaborators, cooperators or contributers. Importantly, these designations change depending on the level of commitment or semantic preference. For example, a project participant is someone who is "part" of the project, but maybe not as involved in its implementation as a collaborator or cooperator (BRUNET, 2009b, p. 71).

Thus, how can the production of collaborative television news programs be improved so as to allow reconfiguration of the teachinglearning process in this scenario? One way is a process that not only involves students preparing for careers as journalists, but also opens opportunities for ordinary people to interact with the media.

\begin{abstract}
Sadly, we have learned in recent years that journalism schools are slow in adapting to the media. This leads to a doubly wrong combination between the requirement in the industry media and training offered at university. The media professionals who are looking to the front, despite being far from it, who are recent graduates, are in effect at the technological forefront, and entering their profession with a lack of training that moves over to the media themselves. Most schools are currently training outdated journalists: they train young people who do not cater to the needs of media companies for urgent restructuring in the digital context. (SALAVERRÍA, 2011, p. 143.)
\end{abstract}

How can universities restructure the curriculum and adapt to train «creative and able to innovate» professionals in a scenario of participatory culture, defined by Shirky (2011), and therefore, avail the cognitive surplus generated by the collective? This means not only being able to manage new technological tools available in the market but also conceiving the practical and productive routines in journalism from the culture of sharing, cooperating and collaborating with the audience.

In this context, collaboration undertaken by ordinary people becomes crucial, encompassing the ability to resist the effects or confrontation of the media, as well as tell the reporter what they can publish. Nonetheless, the roles are reversed to the extent that the editorial policies of major media companies recommend that journalists produce content by stepping into the shoes of the reader. They are responsible 
for imagining what the reader would like to see published. With digital resources, ordinary people have the opportunity to try to mitigate or even reverse the situation, in certain cases.

Professional culture still tends to minimize the audience's role in journalism. The open spaces for participation, collaboration and interaction with the public generally seek business strategies to gain audience and consequently sponsors. Common citizens do not always contribute to the production of journalism as a routine, whether it be news selection, production or editing. Universities are also responsible for acknowledging the "civic value" of cognitive surplus generated by public journalists. This is a complex task, as Shirky has noted (2011, p. 162): "Creating a culture of participation with greater benefits for society is more difficult than sharing funny pictures. Concerning social change, are we able to understand?" It is the role of journalism courses to stimulate this change in the formative basis of new professionals. Reconfigurations of present opportunities are needed in the mediating role of the profession and its dialogue with the public. Certainly, notwithstanding the tools and digital media, "the sharing itself is a human, not technological, trait". Collaborative work is necessary between students and teachers, which goes beyond the use and management of digital tools, and enable the development of collaborative learning projects.

However, with respect to changes technologies cause in the production of journalistic content, a broader and problematizing understanding of the issue seems necessary. Debate should not be regarded merely as an answer to ascertain who contributes more in the process of journalistic content production: the journalist or ordinary people. It is paramount to present to the listener what is said, shared, and constructed as a group. Therefore, the process of producing the informational content of television programs created by journalists and ordinary people should be discussed in the context of collaboration.

Since learning to live together and work collaboratively is one of the pillars of CSCL (Computer Supported Collaborative Learning), it is observed an enhancement on the collaborative dynamics in the context of teaching and learning of journalistic phenomenon. Authors like Stahl and others (2006) highlight the significance of learning sciences that examine how people can learn to work in groups with the help of computers: "Within the tools of Web 2.0, 'social media' and social networks are penetrating college due to the opportunities to increase student participation, enhance their creativity and bring a new perspective to the socialization process" (CABERO; MARIN, 2013, p. 166).

These demands to develop new learning skills and work 
collaboratively in groups, which feature in the implementation of the JCollab tool, constitute the creation and management of digital television newscasts by virtual communities organized into a social network, via the Internet. The technological implementation of JCollab research came after the approval of the project in the Tecnologias e Soluções para Suporte a Conteúdos Digitais program, financed in Brazil the Rede Nacional de Ensino e Pesquisa (RNP) in 2010.

JCollab' $^{1}$ is an innovative tool, since it combines an automatic telejournalistic process of creation, production and broadcast, with the use of the Web 2.0 platform. Before, tools developed for journalism in digital databases were migrating to the genre of web journalism, including BrasilWiki, NewsTrust, Digg. Mielniczuk (2001) suggests the term "web journalism" to designate all journalistic activity aimed at newspapers publishing content online.

\section{COLLABORATIVE, PARTICIPATORY AND OPEN-SOURCE JOURNALISM}

These journalism models are structured around the appropriation of information and communication technologies (ICT). Access to mobile and portable devices to capture, produce, and access digital networks, specifically Web 2.0, with the publication and dissemination of projects, allows group work and sharing between members of one or more communities with common interests. Furthermore, organizations and journalists are affected by these changes and new skills brought by technologies.

The change in information consumption and flexibility in creating and disseminating content for the audience, poses challenges to the hierarchical structure of transmitter and receiver. There is a greater appreciation of participation by the audience member, who feels a part of the newscast through helping to produce news. According to Domingo et al. (2008, p. 327), participatory journalism makes institutional journalism find a new agent function, producing an alternative agenda.

The authors acknowledge that even in participatory journalism, traditional media dominate news product production since "This model assumes that some communication functions institutionalized by agencies and news media can be performed by individual members of society and social organizations, while other functions are still concentrated in the hands of communication institutions." (DOMINGO et al., 2008, p. 331.)

In this digital scenario, the concept of collaborative journalism 
is also significant, and it is broader than participatory journalism. It demands greater contribution and responsibility in one of the production process phases, sharing with collective journalism some stages of the journalistic routine.

At first, the public was just the source, with collaborative journalism they were turned into reporters. However, in the middle of the path, there is a lack of mediation of basic information, which should be carried out by journalists and ordinary people, promoting professional development and learning of modes of media by the public (ROCHA; BRAMBILLA, 2010, p. 2015.)

Open-source journalism brings the logic of collaborative and virtual work present in computers together with the cooperation and sharing of data and code, produced collectively by any user member from the community. "...the designation of open-source, as used in open-source journalism, is a way to allow the source (or surfer) to alter the information available on databases, similarly to what happens on Wikipedia" (ZANOTTI, 2010, p 32.). Contextualizing open journalism in the news genre, code reports or even a picture from televised news, can be developed by accredited partners that, sometimes adopted by broadcasters, are produced under the supervision of a professional company.

With respect to JCollab, a journalism student or citizen from the newscast community is responsible for producing the news, in addition to suggesting and choosing the best guideline in the final product presented as a potential news item. Also, the chief editor of the news program is a professional who oversees the process. The key principle is the sharing of responsibilities and cooperation on the newscast production process, since it is believed that:

With an active and interactive dialogue between professional journalists and individuals connected to the network, citizen/ journalists as termed by some, it is possible to reduce the knowledge gap on issues of public importance. It is possible to engage citizens in digital democracy. (PAVLIK, 2011, p. 111-112.)

The information produced by any user together with the journalist can expand programming and place on the agenda issues that could be rejected by journalists for not being deemed of common interest, because they wouldn't "have enough newsworthiness or meet the criterias", adopted by the editing of news or the professional. The recommendation is that, via a process of "collaborative gatewatching", one can work together with citizens so as to develop a shared understanding of the news (BRUNS, 2008). 


\section{JCOLLAB AS A TOOL FOR COLLABORATIVE PRODUCTION}

The aim of the JCollab project is to form a convergent context, structure the development of a creative and interactive process of producing television news and collaborative programs from journalists' communities, united virtually by the desire to produce and disseminate information of their interest. The concept of open-source journalism is one of the foundations of this proposal, a mode that structures journalistic work to be carried out by more than one person. Brambilla (2005, p. 09) claims that "in open-source journalism, the individual who reads also writes news, shares responsibilities and has personal involvement as their primary bargaining chip».

In addition to open-source journalism, the principles of participation, cooperation and collaboration in Web 2.0 also define JCollab workflow. The roles that users play, follow the logic of production present in the journalistic routine, as functions and activities of doing journalism. As in open source journalism, productive flow depends on activities performed by the following actors: chief editor, publisher, and reporter. These members are inserted and engaged in developing the community program.

The user-audience can either be individuals who wish to continue to participate as community members, or who simply want to visit it. Sometimes, they merely desire to offer suggestions. From the practical production of informational routines present in television newsrooms, JCollab workflow was developed by creating a cycle of adding virtual and collaborative production processes through participatory communities that make up the social network.

Figure 1 Story production cycle in a collaborative newscast using JCollab _

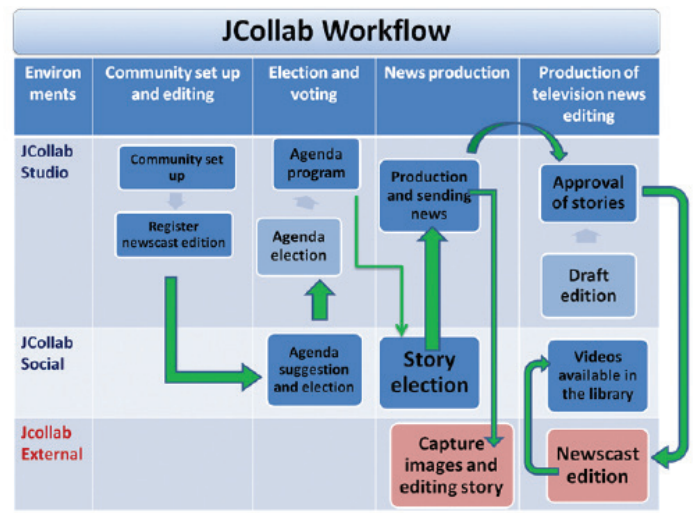

Source: Created by Kellyanne Alves 
JCollab helps students and journalists to construct news issues collaboratively through the interaction -including suggestions, votes, collaboration and production of stories - of a community of users associated with the newscast. Additionally, the production community can interact with each other through social networking functionalities. The workflow is provided by the process of establishing a news editor by community members, who can choose the features: chief editor, editor, and / or reporter.

The steps shown in the figure above require activities by a chief editor or publisher-editor, while the actions within squares are related to the activities of reporters (or even spectators), as in the case of agenda voting. Each block in the picture above can be interpreted as the state of an issue. An issue may be at the "suggestion and vote on agenda items" stage, or the "pick agenda" stage, etc.

The transition between states occurs temporarily by information (dates and times) provided by the chief editor in the issue record. Once defined, for example, the slots in which an issue is open to suggestions and voting on agenda items, prior transitions to this state and, consequently, from that state to the next, occur in a transparent and automatic way. All users rely on the functionality of the social network and, within each community, a user can have one or more identified roles: audience, reporter, publisher-editor (specific to a section) and chief editor. The user roles developed by the Social Scene community are:

Activities on the social network: recording and editing profile pictures, following other users, checking the latest activities of other users, sending messages to other users, checking the communities in which users participate, checking the "portfolio" of other users, searching for content, watching videos in the video library, commenting and 'liking' them.

Activities of a spectator: in addition to those on social networks, a newscast user-audience can do the following: suggest agenda items and vote for issues suggested.

Activities of a journalist: If the user chooses to participate in the production of an article, they can take on the role of a reporter, and in turn, can: choose agenda items, include and edit metadata associated with an article, upload their video of a story.

Activities of a publisher-editor: TV news managers assume the tasks of both writers (specific to a section) and chief editors. The publisher-editor has the following prerogatives in a section: managing suggestions for agenda issues submitted by the community; evaluating videos submitted by reporters; choosing one of the videos posted to compose the draft edition. 
Activities of an editor: the editor acts as an editorwriter in all sections. Furthermore, they can: create and edit sections; approve the participation of members and publishers in the community, create and edit issues, change the logo and information of the newscast; download all the stories from the draft, change the order of the draft stories; compose the complete final editing.

\section{JCOLLAB ENVIRONMENT DESCRIPTION}

Suggested Agenda: The user suggests a topic for the news. The suggestion process takes place on a local JCollab social network intended for the audience to suggest and vote for the agenda items that will be part of the program editing. To suggest an agenda item, the user does not need to participate in a community. Voting on the agenda is performed on the JCollab homepage because, in order to vote, the user has to be a part of the community, the audience.

The user-audience is any member of the community, or whoever simply enters to visit, vote on and view the program. When the user-audience suggests a theme, they select the subject of the story. At this stage, the user only has to put forward an agenda (or topic) they want, filling out the following information: the subject of the story, focus desired and section. Sections are used to classify agendas, such as: politics, economy, international, culture, sports and technology.

Another way to suggest agenda items is through the studio environment, via the user editor in chief and publisher-editor, both of whom can suggest agenda items and vote on the JCollab homepage community.

Figure 2 Display of the suggestion environment agenda on the social network

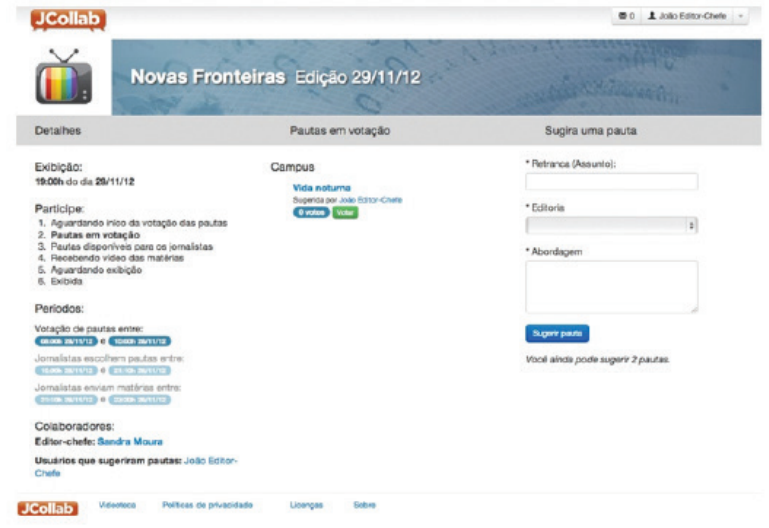

Story production: when reporters select the agenda in the social environment, the reporter's name appears besides the name of the 
agenda chosen. This allows the system to detect and send a list of reporters with stories chosen for the editor, who will thus know how many people have chosen to produce a given agenda. Also, if an agenda has not been selected by any reporter, the system designates it to the editor, who can send a message via social network to encourage a userreporter without an agenda to produce it.

In the studio environment, the article section is the area in which the reporter has room to write a detailed agenda, video production schedule, credits and the story script, known as voice over. The production process of the story is the reporter's responsibility. They produce their interviews, and capture and edit images in their editing software. Once the video is ready, the reporter saves the story in their environment studio. Draft: environment in which the user-chief editor and publisher-editor analyze news published by reporters. The analysis defines the complete draft; the skeleton of the program. Selected stories come in editing the news. Stories are related to an agenda for each topic. This ensures a greater diversity in subjects reported. The analysis compiled by the publishereditor and editor is performed according to the criteria of journalistic newsworthiness. Voting is done in the studio environment. Users classify issues into "bad", "fair", "good" and "excellent", taking into account the degree to which they fulfill newsworthiness criteria, which are: relevance, originality and public purpose, as well as quality of picture and sound. They were defined following a study of the concepts of newsworthiness and news values used by journalists in their work routine.

Figure 3 Display of the voting environment of suggested agendas on the JCollab Social network and display of the studio environment with daily agenda, voting on the stories and newscast draft

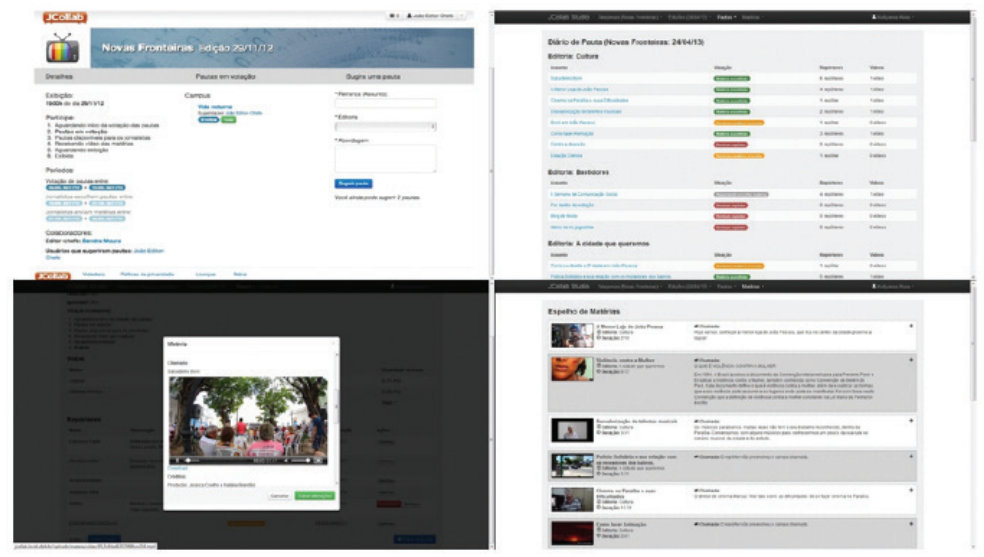


Video Library: site where all community news editions are available. All users of the community and visitors can access the video library.

\section{MATERIAL AND METHODS}

Initially, several professionals and journalism students were interviewed to identify the particular needs and characteristics of the news production routine for developing the JCollab tool. Given the real sector output environments in broadcast journalism, which are present at TV broadcasters, a study of the organizational structure was carried out at that time. (ALVES; SOUZA FILHO; MÉDOLA, 2012)

In developing the tool - beginning in 2010- the collaborative production websites analyzed were Wikinews, Kuro5hin, BrasilWiki, OhmyNews, Digg and NewsTrust (ALVES; SOUZA FILHO; MÉDOLA, 2011 ). These websites were developing daily report videos online, recorded with mobile phones. Regarding the genre of broadcast journalism on the Internet, it was not found in this initial study any website or specialized tool related to collaborative production of news programs through social networking.

Alves, Souza Filho and Médola (2011) studied those sites (Wikinews, Kuro5hin, BrasilWiki, OhmyNews, Digg and NewsTrust) and found little use of multimedia resources (video and audio), generally shared only in text and photos. There was a real study of the environment of broadcast journalism - the editorial environment itself - and such websites offered no collaborative model, in the sense of collaborative construction of news. Hence, the JCollab approach has arisen.

In its final version, JCollab was implemented using the Ruby programming language and Ruby on Rails framework to develop web applications. This was due to several factors: the popularity and maturity of the framework (which facilitates the search for documentation and support) and the fact that it is considered an agile development framework, where one can focus on business logic. Another important factor was the previous familiarization of some members of the research team with the development environment. The database used was MySQL, which is also quite popular in web applications by virtue of being free and relatively fast.

The work organization team took into account the following aspects: data collection, evaluation of material, audience analysis in participatory and collaborative processes and generation of results. The 
research methodology is characterized by the hypothetical-deductive method (LAKATOS; MARCONI, 1983), using the comparative method and statistical methods, comprising technical documentation of indirect and direct documentation. From extensive direct observation, testing and collection of material for analysis were performed with journalism students on JCollab.

\section{APPLICATION OF JCOLLAB AS A TOOL FOR COLLABORATIVE LEARNING}

The tests were applied to groups of journalism and broadcasting students at the Federal University of Paraíba (UFPB), João Pessoa campus, Paraíba, Brazil, and journalism students from the Paulista State University (UNESP), Bauru campus, in Sao Paulo, Brazil. The project team duly conducted three workshops for students and teachers, beforehand. The first two involved counseling communication students from UNESP, taught by Professor Francisco Machado Filho, and the third, students on the UFPB course "New Frontiers for TV", taught by Professor Sandra Moura.

Workshops served to present the first version of the JCollab tool, outlining the flow of news production and steps involved, in addition to the roles and functions of users in the studio and social environments. After testing with groups, questionnaires were applied, with the same questions for all students of the three subjects mentioned above, in order for them to evaluate the tool. As the number of students of the groups was uneven, for comparative purposes, we randomly selected from each group 20 subjects who completed the questionnaires.

In the questionnaire, a score of 0 to 5 was established to assess the following: "What level of interest has JCollab aroused from you?"; "has JCollab contributed to the production of collaborative information programs?"; and "in what context can one apply the tool?". The results of the data obtained through the questionnaire are presented in the following charts:

A) What level of interest has JCollab aroused from you?:

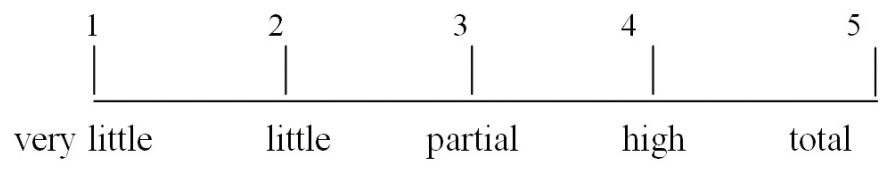


Chart 1 Journalism Group -UFPB -João Pessoa

\section{Percentage}

$=1$ - Very little $\approx 2$ - Little $=3$-Partial $\square 4$ - High $\approx 5$-Total

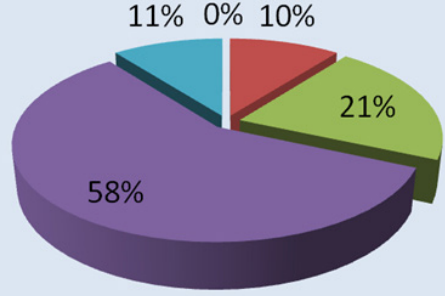

Source: Created by Kellyanne Alves

Chart 2 Group \#1 Journalism - Unesp-Bauru

\section{Percentage}

a-Very little $\quad$ 2-Little $\quad$ 3-Partial $\quad$ 4-High $\quad$ 5-Total

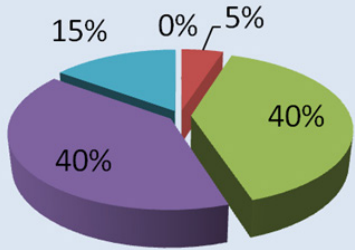

Source: Created by Kellyanne Alves

Chart 3 Group \#2 Journalism - Unesp-Bauru

\section{Percentage}

घ-Very little $\quad 2$-Little $\square$ 3-Partial $\quad$ 4-High $\square$ 5-Total

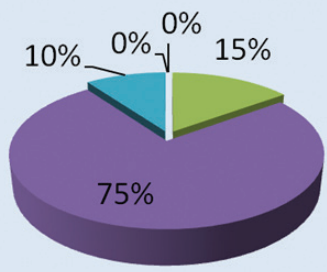

Source: Created by Kellyanne Alves 
In this section, most interviewees felt that the tool aroused "high interest". That was the response of $58 \%$ of students from the UFPB group, 40\% of students from UNESP group 1 and 75\% from UNESP group 2. On this same point, $21 \%$ of the UFPB group felt that the tool "partially" aroused their interest, compared with 40\% in UNESP group 1 and $15 \%$ in UNESP group 2 . The researchers, after analyzing the results of this section, considered it "satisfactory".

B) In your opinion, has JCollab contributed to spread the collaborative production of news programs?:

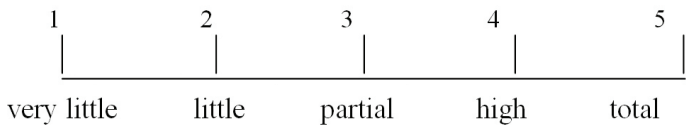

Chart 4 Journalism Group - UFPB -João Pessoa

\section{Percentage}

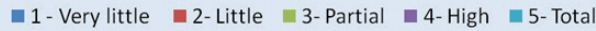

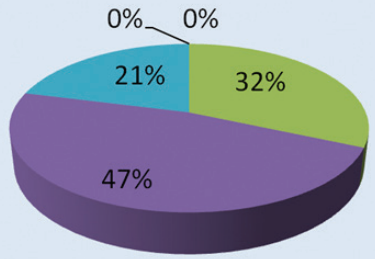

Source: Created by Kellyanne Alves

Chart 5 Group \#1 Journalism - Unesp-Bauru

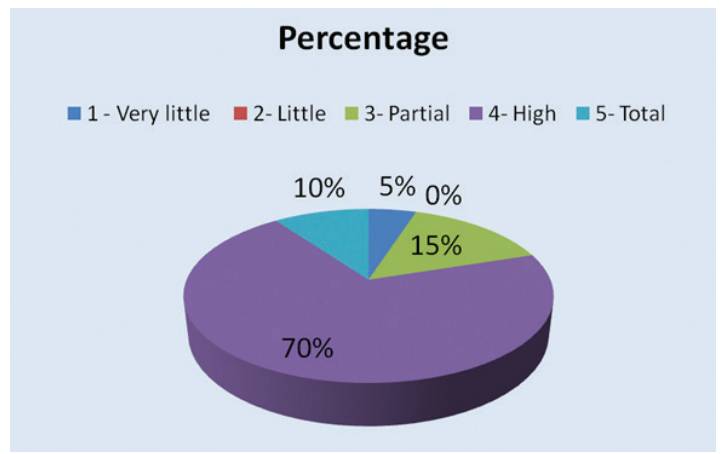

Source: Created by Kellyanne Alves 
Chart 6 Group \#2 Journalism - Unesp-Bauru

\section{Percentage}

$\approx 1$ - Very little $\square 2$ - Little $=3$ - Partial $\square 4$-High $\equiv 5$ - Total

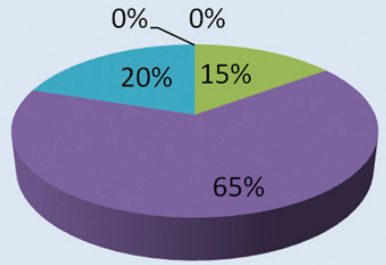

Source: Created by Kellyanne Alves

Regarding the contribution of the tool in producing news programs, most interviewees felt that JCollab magnified collaborative production, as stated by $60 \%$ of the students in the UFPB group, $70 \%$ from Bauru group 1, and 65\% from Bauru group 2. For this section, 32\% of UFPB students, along with $15 \%$ in UNESP group 1 , believed that the tool had "partially" contributed to that type of production. However, 20\% of interviewees from Bauru Group 2 felt that the tool had increased production "totally". The project team also considered the end result of this section "satisfactory".

C) In what context do you think that JCollab can be applied?:

1. ACADEMIC 2. TRAINING 3. BOTH 4. NONE

Chart 7 Journalism Group - UFPB -João Pessoa

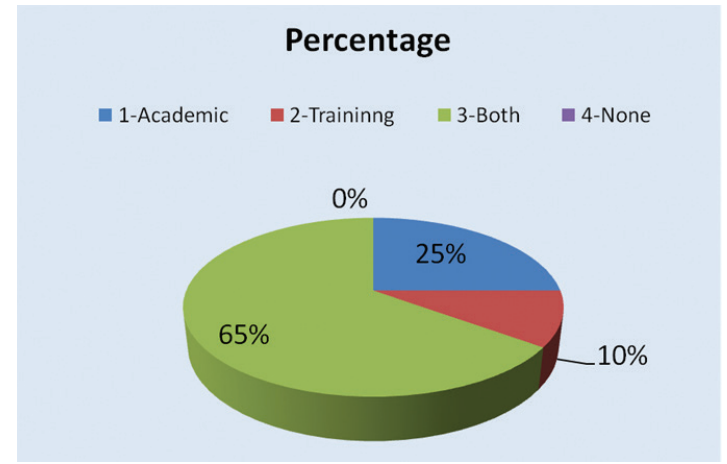

Source: Created by Kellyanne Alves 
Chart 8 Group \#1 Journalism - Unesp-Bauru

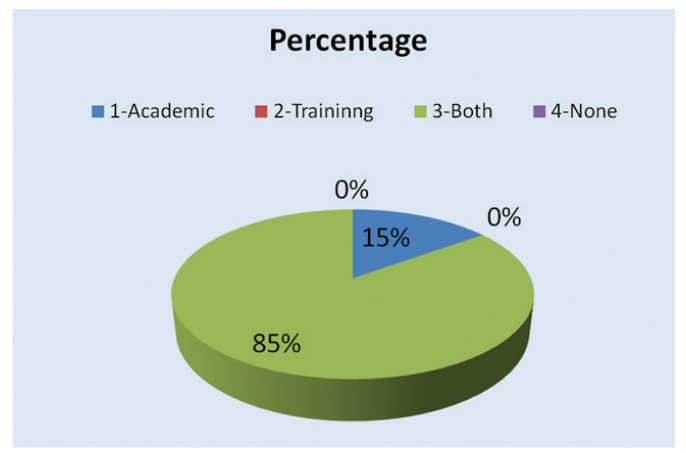

Source: Created by Kellyanne Alves

Chart 9 Group \#2 Journalism - Unesp-Bauru

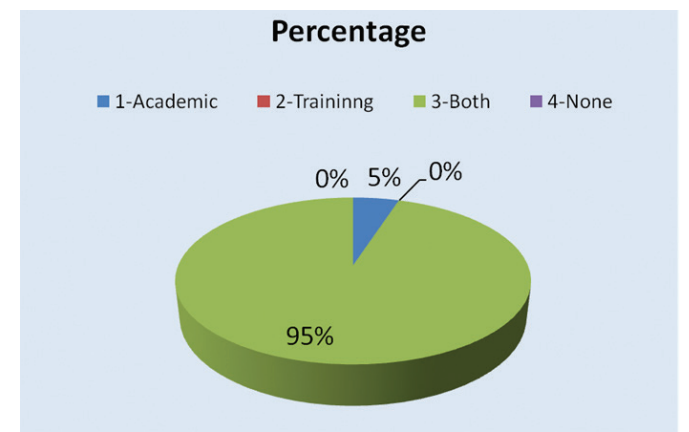

Source: Created by Kellyanne Alves

With respect to the application of JCollab in academic and professional contexts, most interviewees voted for "both" contexts. 65\% of students from the UFPB group, 85\% from Bauru group 1 and 95\% from Bauru group 2 considered that the tool could be used in both fields. Meanwhile, 25\% of students from the UFPB group, 15\% in Bauru group 1 and $5 \%$ from Bauru group 2, believed the tool could only be applied to an academic context. The project team considered this section "relevant", since the proposed tool was intended initially for education and training.

After the sudents' evaluation of the three subjects, the next phase was to produce a TV program using JCollab, during the New Frontiers for TV course at UFPB and thus test the tool in the context of teaching and learning. During the test, conducted in 2012 over an academic semester, students were users of the tool, selecting the roles they wanted to assume in the production process of a news program. Throughout the implementation of JCollab during the New Frontiers 
for TV course at UFPB as a management tool for operational activities, students chose topics together and produced agenda items, reports, draft and final editions of the program. Professors coordinated the activities that took place both inside and outside the classroom.

UFPB students of Journalism and Broadcasting produced a television program. Novas Fronteiras (New Frontiers) was the name chosen for the news program, with an electronic journal format aimed at professors, students, researchers, intellectuals, artists and other individuals interested in deeper news. The professor was the chief editor, and two students were nominated as publishing-editors.

The student evaluation of the reception and understanding of the proposed tool was well accepted. Greater difficulties were faced in meeting the deadline for the stage of sending the story, since it depended on the use of editing equipment to complete the material.

The final test result was the production of eight stories that made up the final version of the Novas Fronteiras program, lasting 33 minutes and 16 seconds. This news magazine is available at the community library ${ }^{2}$. The JCollab tool, during the New Frontiers for TV course at UFPB, was tested in academic environments, and it can potentially be used in any professional environment.

\section{CONCLUSIONS}

The potential for collaboration can be appreciated not only in JCollab during the New Frontiers for TV course at UFPB, in the field of video uploads produced by the community, but also in the methods and pedagogical approaches. With respect to teaching and learning, the impact of the JCollab collaboration processes during the New Frontiers for TV course at UFPB, occurs on at least three levels: 1) information management and student work; 2) the reorganization of teachers' work, and 3 ) the performance of participants.

In terms of information management and student work, activities carried out by students do not need a fixed physical space. Thus, they can interact with the system without their physical presence being required in class, since a virtual editorial is available.

The possibilities arising from this tool also represent a new type of relationship between students, professors and collaborators involved in the production chain. The link between them enables student section work in collaboration with other editing. This allows learning in a way that enhances collaboration and teamwork stimulus, resulting in a process 
that is done effectively and collectively.

In this network, shared information will not only serve to provide communication between students and professors. The establishment of this environment also connects students with collaborators. From the professor's perspective, even though the action of coordinating the activity is on their behalf, their work is reorganized on the JCollab platform. Professors perform management functions on a collaborative platform, corresponding to those of a chief editor.

Undoubtedly, information is shared, stories are built collaboratively (knowledge is exchanged among students, teacher-reviewers and users), facilitating communication between group members.

This communication, which manifests itself through JCollab, works as a catalyst for joint decision-making throughout the production process. Ransdell (apud SALLES, 1990, p.76) asked: "What is communication if not the production of signs to be interpreted?". For Roman Jakobson (1995, p.21), when it is stated that language or any other sign system is used as a means of communication, restrictive conceptions of media and communication purposes should be avoided. In this regard, Jakobson notes that the nature of intrapersonal communication is as important as the interpersonal dimension.

In this communicative act facilitated by the JCollab tool, professors guide the investigative work, preparation and publication of stories. Further, professors can do this in a dialogical and collective fashion, that is to say, simultaneously for all students and staff involved in the process. Likewise, they can devise guidelines remotely, at any time, from home, school, or anywhere, without needing to be physically by students' computers.

In the JCollab environment, professors visualize every stage of the process, with constant access to the overall picture with the students' and collaborators' suggestions, as well as their own, facilitating decision-making, i.e. choosing the direction that will lead the team to address and solve problems in the stories. In short: they can interact with all collaborators.

In this case, interaction is essential in ensuring that learning takes place, not to mention that group heterogeneity (professors, students, staff members) favors the construction of knowledge through this dialogical action. According to Dillenbourg (1999), the goal of collaborative learning is to support education in a specific educational purpose by means of activities that are coordinated and shared through social interactions among group members. 
The performance of collaborators using JCollab goes beyond sending and posting videos. The collaborative tool represents a space for dialogue and joint construction of public issues. Collaborators are given opportunities to speak with their own voices or even interact with other users on networks.

Thus, by interacting with other group members, collaborators may provide alternative views on the same subject, expanding sources and acting as coauthors on certain stories. This interaction will also allow ordinary people (denoting here user-contributors) to acquire new knowledge - even if basic - on the values and format of news broadcasting. The use of this tool also promotes increased integration of these citizens with the production process in broadcast journalism.

Future improvements in the JCollab tool might include: the establishment of student communication not only with professors, but also with other students and collaboratoring members, and their sources. This dialogue could be maintained during the preparation of stories. The idea would be to have inquiry access, from the sources to student production before publication in the community.

Regarding teaching impact -assessed here drawing on testimony from students in the classroom - the JCollab tool has helped improve the learning experience and relationships in each community.

Testimonies from students revealed signs that the tool gives students greater freedom to participate and leads to the valorization of their assessment on the proposed topics. They reveal evidence of the student's ability to participate actively and critically in the process of constructing news. Students also indicated that JCollab softens the rigid power hierarchy whereby professors allocate tasks and decide on positions, though determination of the general direction remains under the aegis of professors on the platforms.

Students noted the construction of a dialogue culture, in the effects resulting from the use of the tool, which can be permanent, since access can occur anywhere, anytime. Moreover, updated information is remote. They noted that this procedure facilitates the production process, since no member of the community needs to wait until next class to review, comment, suggest or criticize any matter relating to the process.

Finally, and importantly, the pedagogical functionality of JCollab has forced students to face the reality of sharing knowledge with other system users who are not necessarily partners wishing to pursue a career in journalism, in this case, collaborators. In their own way, they present to the students - future journalists - other worldviews. Further, information that 
seemed to be the exclusive domain of the student, teacher or sources, is also shared with ordinary people, culminating in a collective learning experience.

NOTES

1 The JCollab tool can be found at: http://jcollab.lavid.ufpb.br/.

2 Videos of the Novas Fronteiras library program can be accessed in the community: http://jcollab.lavid.ufpb.br/videoteca.

\section{| REFERENCES}

ALVES, Kellyanne Carvalho; MÉDOLA, Ana Silvia Lopes Davi; SOUZA FILHO, Guido Lemos de. Telejornalismo e Interatividade na TV Digital: uma construção colaborativa e participativa no espaço digital. In: GOBBI, Maria Cristina; MORAIS, Osvando J. de (Org). Televisão Digital na América Latina: avanços e perspectivas. São Paulo: INTERCOM, 2012. p. 237-270.

ALVES, K ellyanne Carvalho; SOUZA FILHO, Guido Lemos de; MÉDOLA, Ana Silvia Lopes Davi. Reorganização no espaço virtual: produção colaborativa da audiência para o jornalismo. In: NETO, Antonio Fausto; FERNANDES, José David Campos (Org). Interfaces Jornalísticas: ambientes, tecnologías e linguagens. João Pessoa: Editora UFPB, 2011. p. 121-150.

AMORIM, Lidiane; FINGER, Cristiane. Telespectador multimídia: o Jornalismo Participativo e seus reflexos no telejornalismo. In: Trabalho apresentado na NP Jornalismo, do VIII Nupecom - Encontro dos Núcleos de Pesquisas em Comunicação. Intercom: Sociedade Brasileira de Estudos Interdisciplinares da Comunicação, XXXII Congresso Brasileiro de Ciências da Comunicação, Natal, p. 1-14. set. 2008. Available at: <www.intercom.org.br/papers/nacionais/2009/ resumos/R4-2048-1.pdf>. Accessed on: 18 jan. 2010.

BELOCHIO, Vivian. A cauda longa da informação e suas implicações no jornalismo: estratégias comunicacionais, remediação e des-re-territorialização. Contemporanea, Salvador, p. 1-27. jun 2009. Available at: <www.portalseer. ufba.br/index.php/contemporaneaposcom/article/.../2676> Accessed on: 12 maio 2010.

BOWMAN, Shayne; WILLIS, Chris. Nosotros, el medio: cómo las audiencias están modelando el futuro de la noticias y la información. Tradução de Guillermo Franco M. The Media Center at The American Press Institute. Colômbia: Casa Editorial El Tiempo, 2003.

BRAMBILLA, Ana Maria. A reconfiguração do jornalismo através do modelo open source. Sessões do imaginário, Porto Alegre, p.87-94. Set. 2005. Available at: <http://revistaseletronicas.pucrs.br/ojs/index. php/famecos/article/viewFile/867/654> Accessed on: 27 jun. 2009. 
BRUNET, Karla. Colaboração e Internet: propondo uma taxonomia de formatos de colaboração em projetos de network. Intercom - Revista Brasileira de Ciências da Comunicação, São Paulo, v.32, no. 1, p. 69-87, jan./jun 2009.

BRUNS, Axel. The active audience: transforming journalism from gatekeeping to gatewatching. In: Paterson, Chris \& Domingo, David (Orgs.) Making Online News: The Ethnography of New Media Production. Peter Lang, New York, 2008.

CABERO, Julio; Marín, VERÓNICA. Posibilidades educativas de las redes sociales y el trabajo en grupo. Percepciones de los alumnos universitários. Comunicar - Revista Científica de Comunicación y Educanión, Andalucía - ESP, v. XXI, no 42, p. 165-172, 2014. Available at: <http:// www.revistacomunicar.com/index.php?contenido=detalles\&numero $=42$ \&articulo=42-2014-16>. Accessed on: 14 jan. 2014.

DILLENBOURG, Pierre. What do you mean by "Collaborative Learning?. In: Dillenbourg, Pierre Collaborative Learning: Cognitive and Computational Approaches. Oxford, UK: Elsevier Science, 1999.

DOMINGO, David et ál.. Participatory journalism practices in the media and beyond: An international comparative study of initiatives in online newspapers. Journalism Practice - Special Issue: The Future of Newspapers, v. 2, ed. $3^{a}, 2008$, p.326-342. Available at: http://www.tandfonline.com/doi/ pdf/10.1080/17512780802281065. Accessed on: 14 jan. 2014.

GILLMOR, Dan. We the media: grassroots journalism, by the people, for the people. Sebastopol: O’Reilly Media, 2004. Available at: <http://www.oreilly. com/catalog/wemedia/book/index.csp>. Accessed on: 02 dez. 2013.

JAKOBSON, Roman. Linguística e Comunicação. São Paulo: Cultrix: Edusp, 1995.

JENKINS, Henry. Cultura da convergência. Tradução de Susana Alexandria. São Paulo: Aleph, 2009.

LAKATOS, Eva Maria; MARCONI, Marina de Andrade. Metodologia do Trabalho de Pesquisa. São Paulo: Altas, 1983.

MIELNICZUK, Luciana. Considerações sobre interatividade no contexto das novas mídias. In: LEMOS, André; PALACIOS, Marcos (Orgs.). Janelas do Ciberespaço: comunicação e cibercultura. Porto Alegre: Sulina, 2001.

PAVLIK, John V. A tecnologia digital e o jornalismo: as implicações para a Democracia. Brazilian Journalism Research - journalism theory, research and criticism, São Paulo, v.7, n. 2, p.94-1 18, 2011 . Available at: < http://bjr. sbpjor.org.br/bjr/article/view/340/314>. Accessed on: 15 jan. 2014.

ROCHA, Jorge; BRAMBILLA, Ana Maria. Comunicação relacional e as mediações possíveis no Jornalismo Colaborativo. In: SCHWINGEL, Carla; ZANOTTI, Carlos A. (Orgs.). Produção e colaboração no Jornalismo Digital. Florianópolis: Insular, 2010, p. 205-216.

SALAVERRÍA, Ramón. O ciberjornalismo encontra a universidade: ideias 
para melhorar o ensino e a pesquisa. Brazilian Journalism Research - journalism theory, research and criticism, São Paulo, v.7, $\mathrm{n}^{\circ}$. 2, p. 141-157, 2011. Available at: <http://bjr.sbpjor.org.br/bjr/article/ view/343/316>. Accessed on: 15 jan. 2014.

SALLES, Cecília Almeida. Uma criação em processo, Ignácio de Loyola Brandão e Não Verás País nenhum. Tese (Doutorado em Comunicação e Semiótica). Pontifícia Universidade Católica de São Paulo, 1990.

SHIRKY, Clay. A cultura da participação: criatividade e generosidade no mundo conectado. Trad. Celina Portocarrero. Rio de Janeiro: Zahar, 2011.

STAHL, Gerry et ál.. Computer-supported collaborative learning. In: R. Keith Sawyer, Cambridge handbook of the learning sciences. Cambridge (UK): Cambridge University Press, p. 1-20. 2006. Available at: <http:// gerrystahl.net/cscl/CSCL_English.pdf>. Accessed on: 31 maio 2013.

Kellyanne Carvalho Alves MSc in Digital TV from the Universidade Estadual Paulista. Researcher at the Digital Video Application Lab (LAViD). E-mail: kellyanne@lavid.ufpb.br

Guido Lemos de Souza Filho PhD in Computer Science from the Pontificia Universidad Católica de Río de Janeiro. Postgraduate profesor of IT. Professor on the Professional Master's program in Journalism at the Universidade Federal de Paraíba (UFPB).E-mail: guido@lavid.ufpb.br

Sandra Moura PhD in Communication and Semiotics from the Pontificia Universidade Católica de Sao Paulo (PUC-SP). Professor on the Professional Master's program in Journalism at the Universidade Federal de Paraíba (UFPB). E-mail: sandramoura@ccta.ufpb.br

Fernando Brito Undergraduate Computer Science student at the Universidade Federal de Paraíba. Researcher and Developer at the Laboratorio de Aplicaciones de Vídeo Digital (LAViD). E-mail: fernando@lavid.ufpb.br

RECEIVED ON: 15/08/2013 | APPROVED ON: 17/03/2014 